\title{
Human Newborn Hypergastrinemia: An Investigation of Prenatal and Perinatal Factors and Their Effects on Gastrin
}

\author{
ARTHUR R. EULER ${ }^{(13)}$, MARVIN E. AMENT, AND JOHN H. WALSH \\ Division of Gastroenterology, Departments of Pediatrics and Medicine, University of California, School of \\ Medicine, Los Angeles, California, USA
}

\section{Summary}

Because gastrin is a potent gastric acid stimulus and gastric acid secretion begins soon after birth, we measured umbilical cord serum gastrins. We also examined multiple factors present during the gestation, labor, delivery, and immediate postpartum period to see what effect, if any, these might have on the serum gastrins.

Two groups were studied: 217 newborn infants and 802 adults without Zollinger-Ellison syndrome. The newborns' median serum gastrin was $100 \mathrm{pg} / \mathrm{ml}$ compared to the adult median of $39 \mathrm{pg} / \mathrm{ml}$. The newborn mean was $135 \mathrm{pg} / \mathrm{ml}$ and the corresponding adult value was $40 \mathrm{pg} / \mathrm{ml}(P<0.001)$. Twenty-nine newborns had gastrin determinations greater than $200 \mathrm{pg} / \mathrm{ml}$; five were greater than $500 \mathrm{pg} / \mathrm{ml}$. All adult values were less than $200 \mathrm{pg} / \mathrm{ml}$.

Thirty-five neonatal and maternal factors were analyzed to determine their effect on the gastrin levels found. No factor was found to have a significant effect except that Negro infants and maternal sickle cell trait were found to be associated with increased values. Nineteen maternal medications were also evaluated. None, including oxytocin and atropine, were found to have any effect.

Serum gastrin levels continued to be elevated at hour $4(\bar{x}=$ $80 \mathrm{pg} / \mathrm{ml})$ and hour $8(\overline{\mathrm{x}}=72 \mathrm{pg} / \mathrm{ml})$ of life. The newborns secreted small amounts of gastric acid in response to this stimulus (range $=0.010$ to $0.022 \mathrm{mEq} / \mathrm{kg} / \mathrm{hr}$ ).

\section{Speculation}

During the transition to extrauterine life, the fetus is exposed to many varied stimuli. Increased vagal activity and catecholamine secretion are two physiologic reactions which occur in response to these stimuli. Both of these are known to stimulate gastrin release from $G$ cells during extrauterine life and may account for the increased levels found at the time of delivery. The elevated gastrin levels found after birth may also be in response to these factors; however, decreased metabolism may play a role too. It is known that the kidney is the major site for gastrin metabolism in adults. The newborn kidney may not be capable of rapidly metabolizing the large gastrin load presented to it during these first hours of extrauterine life. Continued high secretion of gastrin by the $G$ cell may also play a role in the elevated serum levels found.

The low gastric acid secretion in response to these high gastrin levels may be due to decreased parietal cell responsiveness during this period of life. Decreased parietal cell mass could also be responsible. Finally, if the predominant gastrin molecule was not the G-17 moiety, decreased acid secretion would be expected.

Gastrin is a peptide hormone secreted by the $G$ cells of the antral pyloric glands and proximal duodenum (5). It is a potent stimulus for hydrochloric acid production by the parietal cells of the fundic mucosa (3). The release of gastrin from antral and duodenal mucosa is augmented by multiple stimuli, including antral distension, vagal stimulation, catecholamines, polypeptides, and amino acids (11). We, therefore, determined gastrin levels in the cord blood and concomitantly examined multiple prenatal and perinatal factors to find what effect, if any, they might have on the gastrin levels we found. Serum gastrin was also determined during the first hours of life while gastric acid secretion was monitored in the infants.

\section{MATERIALS AND METHODS}

Two hundred seventeen infants had mixed venous and arterial samples obtained from the umbilical cord of the placenta immediately after delivery of the infant. The last six newborns in our study also had fasting venous samples obtained at 4 and 8 $\mathrm{hr}$ postpartum. All samples were allowed to clot and were centrifuged immediately at $200 \mathrm{rpm}$ at $5^{\circ}$ for $30 \mathrm{~min}$. The serum was removed and immediately frozen at $-20^{\circ}$. Serum gastrin was determined in duplicate by radioimmunoassay.

Eight hundred two adults who had peptic ulcer disease symptoms but did not have Zollinger-Ellison syndrome or peptic ulcer disease were used as control subjects. Venous blood samples were obtained after an overnight fast and treated in the same manner as in the infants.

The last six newborns in our study had nasogastric tubes placed immediately after birth. Ten milliliters of sterile water were placed in the stomach and the tube was repositioned until all the water could be removed. Continuous aspiration was then maintained for $8 \mathrm{hr}$ by a suction pump (negative pressure 3-5 $\mathrm{cm} \mathrm{H}_{2} \mathrm{O}$ ). The machine suction was interrupted frequently and manual aspiration applied to document that the nasogastric tube was patent. Volume, $\mathrm{pH}$, and hydrogen ion concentration were measured on 1-hr samples for the $8 \mathrm{hr}$ of study. Titration end point was $\mathrm{pH} 7.0$.

Fourteen children with functional abdominal pain (age range = 4-14 years) had basal acid secretory studies performed exactly as described above and served as control subjects.

The following statistical methods were used to analyze our data: (1) Student $t$-test for unpaired means; (2) linear regression analysis; (3) one-factor analysis of variance.

\section{RESULTS}

The newborns had a median serum gastrin of $100 \mathrm{ps}$ 'ml compared to an adult median of $39 \mathrm{pg} / \mathrm{ml}$. The newborn mean was $135 \mathrm{pg} / \mathrm{ml}$ with SE of 7.57 . The corresponding adult value was $49 \mathrm{pg} / \mathrm{ml}$ with an SE of 3.18 . The means are highly significant with a $P$ value of $<0.001$. Figures 1 and 2 show the distribution of gastrin values found in both groups. Twenty-nine newborns had gastrin determinations greater than $200 \mathrm{pg} / \mathrm{ml}$ and five had values greater than $500 \mathrm{pg} / \mathrm{ml}$. Gastrin levels 


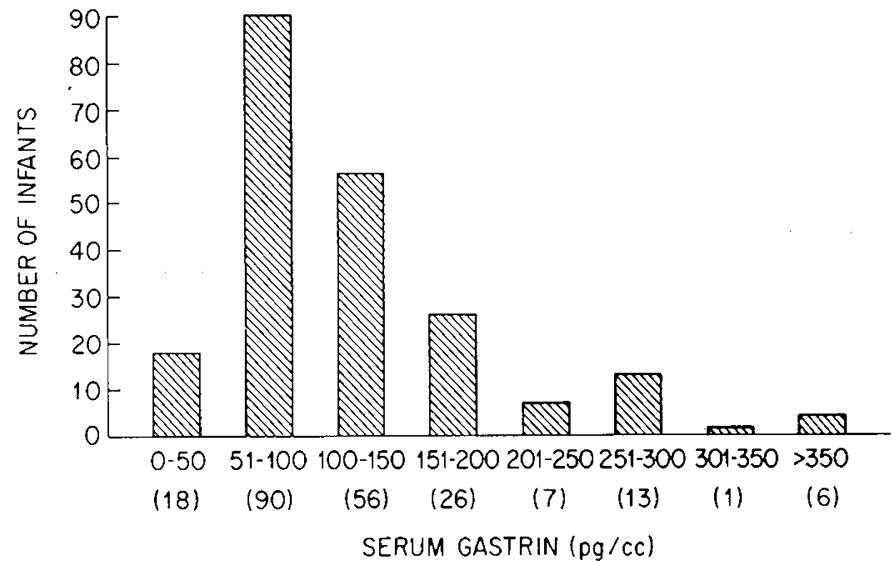

Fig. 1. Distribution of mixed umbilical cord serum gastrin values in human newborns.

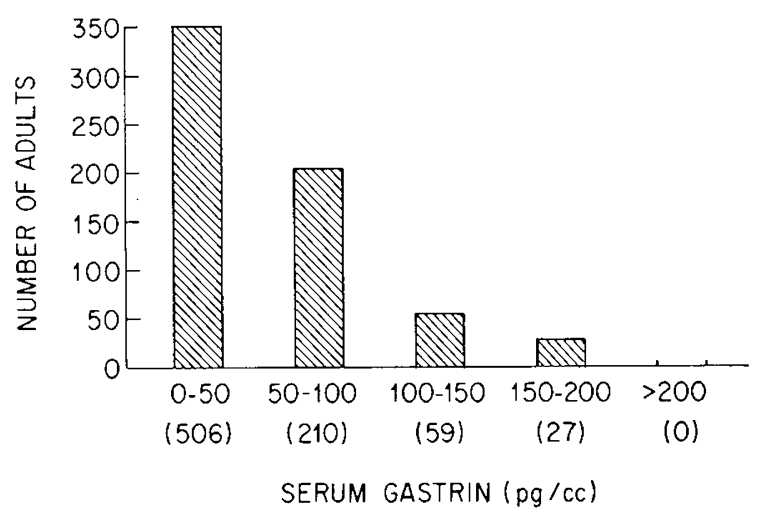

Fig. 2. Distribution of venous serum gastrin values in fasting adults.

greater than $200 \mathrm{pg} / \mathrm{ml}$ were not found in any adult sample. Maternal age, birth weight of the infant, infant sex, 1- and 5min Apgar scores, type of delivery, meconium staining of the amniotic fluid, gestational age of infant, nutritional status of newborn, maternal disease including a history of peptic ulcer disease, maternal preeclampsia or eclampsia, and obstetric conditions such as a prolonged first stage of labor or precipitous delivery were found to have no significant effect on the serum gastrin found when a stepwise regression approach was applied for analysis.

The maternal diseases and obstetric conditions encountered during our study are shown in Table 1 . None of these had any effect on serum gastrin except for the observation that two of the highest values found were in newborns whose mothers had sickle cell trait $(1000 \mathrm{pg} / \mathrm{ml}$ and $270 \mathrm{pg} / \mathrm{ml})$. These were, however, the only two mothers with this disease in our study.

The maternal medications listed in Table 2 were found to have no effect on the level of serum gastrin found in the newborn. The mean log gastrin values for the three ethnic groups in our study (Caucasian, Chicano, and Negro) were $1.97,2.029$, and $2.16 \%$, respectively. These correspond to serum levels of 93,107 , and $147 \mathrm{pg} / \mathrm{ml}$. Analysis of variance of these log gastrins yielded an $F$ statistic of 4.7 which is significant at the $5 \%$ level. Although neither the presence of drug administration nor maternal disease was significantly predictive of gastrin levels, the incidence of these factors was higher in the Negro mothers. Serum gastrin values at hr $4(\overline{\mathrm{x}}=80 \mathrm{pg} / \mathrm{ml})$ and $\mathrm{hr} 8(\overline{\mathrm{x}}=72 \mathrm{pg} / \mathrm{ml})$ were significantly lower than those found at the time of delivery $(P<0.001, P<0.005)$. They were however, still higher than normal fasting adult values $(P<0.01$, $P<0.05$ )

Results of the basal acid secretory studies are shown in Table 3. Newborn gastric acid production was significantly less for the entire 8 -hr period than older children's $(P<0.001)$.
Table 1. Maternal diseases and obstetric conditions found during study of newborn serum gastrin

Cesarian section (34 patients) (21 nonrepeat)

Meconium staining of amnionic fluid (13)

Positive PPD skin test (9)

Total duration of labor $<3 \mathrm{hr}(8)$

Prolonged first stage of labor $>24 \mathrm{hr}(8)$

Prolonged second stage of labor $>3 \mathrm{hr}(7)$

Preeclampsia (6)

Secondary arrest of labor $=$ no progress past $5 \mathrm{~cm}$ (5)

Gestational diabetes mellitus requiring insulin (4)

Anemia with $\mathrm{Hgb}<10 \mathrm{~g} \mathrm{(4)}$

Premature rupture of membranes $>12 \mathrm{hr}(4)$

Eclampsia (3)

Amnionitis (3)

Breech delivery (3)

Positive VDRL (3)

Epilepsy (3)

Cardiovascular disease (3)

Rheumatic (1)

Congenital (1)

Thromboembolic (1)

Sickle cell trait (2)

Placenta previa (2)

Tuberculosis (2)

Table 2. Maternal medication taken during study of newborn gastrin levels

Nitrous oxide (27 patients)

Oxytocin (22)

Magnesium sulfate (23)

Mepivacaine hydrochloride (14)

Meperidine hydrochloride (13)

Sodium thiopental (10)

Hydroxyzine hydrochloride (10)

Promethazine hydrochloride (8)

Phenobarbital (8)

Atropine sulfate (6)

Penicillin (4)

Isoniazid (4)

Furosemide (3)

Chlorpromazine (3)

Morphine sulfate (2)

Hydroxyzine pamoate (2)

Digoxin (1)

Kanamycin (1)

Clindamycin (1)

Table 3. Basal acid secretion during first $8 \mathrm{hr}$ of life in six newborn infants

\begin{tabular}{cccc}
\hline $\mathrm{Hr}$ & Volume $(\mathrm{ml})$ & $\mathrm{mEq} / \mathrm{hr}$ & $\mathrm{mEq} / \mathrm{kg}$ \\
\hline 1 & 2.8 & 0.032 & 0.010 \\
2 & 3.0 & 0.040 & 0.012 \\
3 & 2.7 & 0.048 & 0.015 \\
4 & 3.0 & 0.035 & 0.011 \\
5 & 2.8 & 0.050 & 0.016 \\
6 & 2.7 & 0.070 & 0.022 \\
7 & 3.0 & 0.065 & 0.020 \\
8 & 3.2 & 0.060 & 0.019 \\
& & & \\
Controls & & 1.30 & 0.035 \\
\hline
\end{tabular}

\section{DISCUSSION}

Newborns in the first hour of life are reported to have an intragastric $\mathrm{pH}$ of between 6.0 and 8.0. The intragastric $\mathrm{pH}$ then decreases to between 1.0 and 4.0 by $4-5$ hr of age $(1,9)$. The stimulus for this acid secretion is unknown. 
It is known that a negative feedback loop exists between fasting serum gastrin levels and gastric acid secretion in normal man (8). Secretion of gastrin by antral $G$ cell is the most potent stimulus known for acid production by the oxyntic cells of the fundal mucosa (3). The increased levels of gastrin we documented in the umbilical cord blood could be a factor contributing to the decrease in intragastric $\mathrm{pH}$ noted after birth.

Adult fasting serum gastrin levels have been reported by a number of investigators and range from $20-100 \mathrm{pg} / \mathrm{ml}(10)$. Values greater than $200 \mathrm{pg} / \mathrm{ml}$ are rarely exceeded in normal adults (11). Thirteen percent of the newborns we studied had cord values greater than $200 \mathrm{pg} / \mathrm{ml}$ with five infants having levels greater than $500 \mathrm{pg} / \mathrm{ml}$, which is in the range of gastrin values found in the Zollinger-Ellison syndrome (11). We do not know why there is any increased percentage of newborns with abnormally elevated gastrin values but the usual causes for hypergastrinemia with hypersecretion of acid (antral G cell hyperplasia, gastric outlet obstruction, Zollinger-Ellison syndrome (11)) have not been reported in the newborn period.

Rogers et al. (6) reported that oxytocin use during labor caused a lower cord gastrin level than when infants were spontaneously delivered. We could not confirm this observation. The mean serum gastrin value for the 22 newborns in our study whose delivery was induced with oxytocin was $106 \mathrm{pg} / \mathrm{ml}$ with an SE of 8.73. The corresponding level for spontaneously delivered infants was $137 \mathrm{pg} / \mathrm{ml}$ with an SE of 8.202. The difference between these means is not significant $(P>0.2)$.

Two other reports, although encompassing smaller groups than our study, agree with our observations that the immediate newborn period is a time of hypergastrinemia $(2,7)$. Neither of these studies, however, analyzed factors which might have contributed to these levels. Our investigation examined multiple prenatal and perinatal factors commonly encountered in obstetric practice. Only two of the many items analyzed had any effect on the newborn gastrin levels. One of these was maternal sickle cell trait. Since only two mothers had this disease, it was impossible to adequately determine whether a significant effect on gastrin levels was exerted by this condition. It was interesting, however, that the infants born to these mothers had two of the highest gastrin levels recorded during our study. The other factor influencing gastrin levels was race. Negro newborns had a significantly higher level of gastrin than either white or Chicano infants. The reason for this is not readily apparent but the presence of drug administration and maternal disease was more frequent in black mothers. Stressful labor and delivery manifested by eclampsia, preclampsia, nonelective cesarian section, meconium staining of the amniotic fluid, lower Apgar scores, younger gestational age, and decreased birthweight were not more frequent among black newborns.

We have documented that newborns' parietal cells do not secrete acid in large amounts in response to the elevated gastrin levels found at the time of birth and during the first hours of life. When compared on a milliequivalent per $\mathrm{kg}$ basis to older childrens' basal acid secretion, newborn infants actually hyposecrete acid in response to this stimulus. We do not know why newborn parietal cells respond in this manner.

The continued elevation in serum gastrin after 4 and $8 \mathrm{hr}$ of fasting is distinctly different from the investigation of Janik $e t a l$. in older pediatric patients (4). In that study, serum values decreased in comparison to basal levels with increasing periods without food. The reason that newborns respond in a manner opposite that of older infants and children when fasted is unknown.

\section{CONCLUSION}

Serum gastrin values were determined by radioimmunoassay in 217 newborn infants and 802 adults. Newborns had elevated gastrin values. Multiple maternal and neonatal factors had no significant effect on those values except for the following: $(1)$ Negro infants and (2) maternal sickle cell trait.

The gastrin levels in newborns remained elevated while fasting during the first $8 \mathrm{hr}$ of life. During this period, the infants secreted only small amounts of gastric acid in response to this stimulus.

\section{REFERENCES AND NOTES}

1. Avery, G. B., Randolph, J. G:, and Weaver, T.: Gastric acidity in the first day of life. Pediatrics, 37: 1005 (1966).

2. Delle, Ware G. F., Asumma, M., and Sopranzi, N.: Neonatal hypergastrinemia. Rendic. Gastroenterol., 7: 36 (1975).

3. Grossman, M. I.: Physiological actions of gastrin. In: L. Demling and R. Ottenjann: Non-Insulin Producing Tumors of the Pancreas (Georg Thieme Verlag, Stuttgart, 1969).

4. Janik, J. S., Akbar, A. M., Burrington, J. D., and Burke, G.: Serum gastrin levels in infants and children. Pediatrics, 60: 60 (1977).

5. Nilsson, G., Yalow, R. S., und Berson, S. A.: Distribution of gastrin in the gastrointestinal tract of human, dog, cat and hog. In: Frontiers in Gastrointestinal Hormone Research (Almquist and Wilsell, Stockholm 1973).

6. Rogers, I. m., Davidson, D. C., and Lawrence, J.: Neonatal secretion of gastrin and glucagon. Arch. Dis. Childhood, 49: 796 (1974).

7. Rooney, P. J., Dow, T. G., Brooks, P. M., and Dick, C. W.: Immunoreactive gastrin and gestation. Amer. J. Obstet. Gynecol., 122: 834 (1975).

8. Trudeau, W. l., and McGiugan, J. E.: Relations between serum gastrin levels and rates of gastric hydrochloric acid secretion. N. Engl. J. Med., 284: 408 (1971).

9. Tudor, R. B.: Peptic ulcerations in children. Pediat. Clin. North Amer. 14: 109 (1967).

10. Walsh, J. H.: Interpretation of serum gastrin values. In: M. H. Sleisinger, and J. S. Fordtran: Gastrointestinal Disease: Pathophysiology-Diagnosis-Management (W. B. Saunders Company, Philadelphia, 1973).

11. Walsh, J. H., and Grossman, M. I.: Gastrin. N. Engl. J. Med., 209: 1324 (1975).

12. We would like to thank Dennis L. Christie, M.D., for providing us with his data on gastric acid secretion in normal children.

13. Requests for reprints should be addressed to: Dr. Arthur R. Euler, Arkansas Children's Hospital, Little Rock, AR 72201 (USA).

14. Received for publication February 18,1977

15. Accepted for publication August 3, 1977. 